\begin{tabular}{|c|c|}
\hline 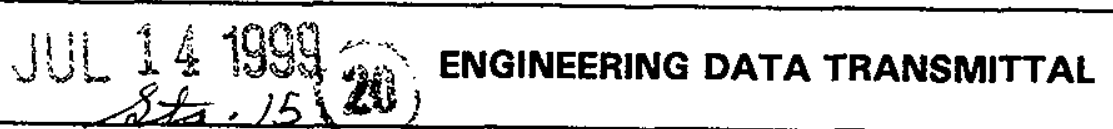 & 1. EDT 6263340 \\
\hline
\end{tabular}

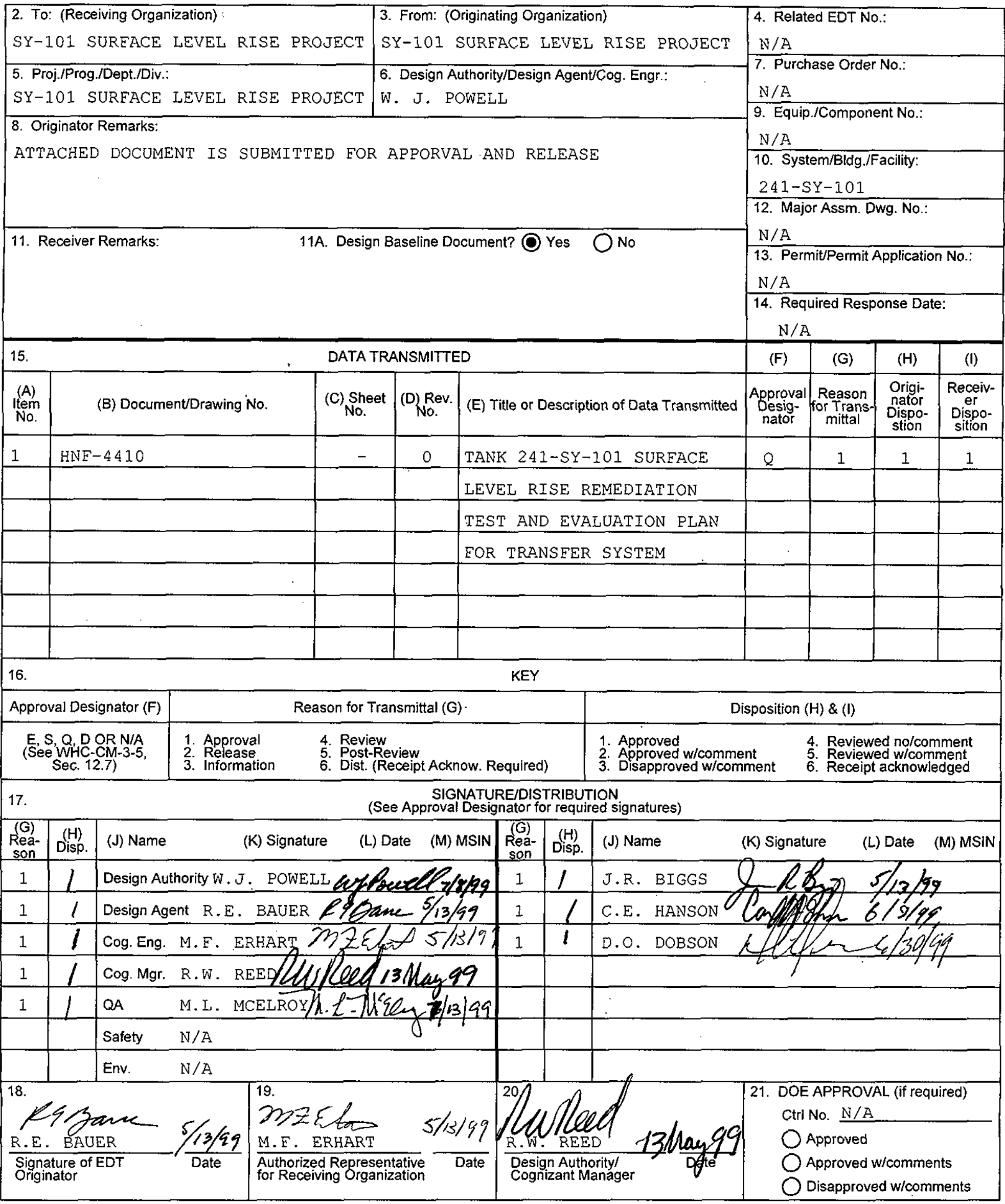




\title{
Tank 241-SY-101 Surface Level Rise Remediation Test and Evaluation Plan for Transfer System
}

\author{
R. E. Bauer
}

Lockheed Martin Hanford Co., Richland, WA 99352

U.S. Department of Energy Contract DE-AC06-96RL13200

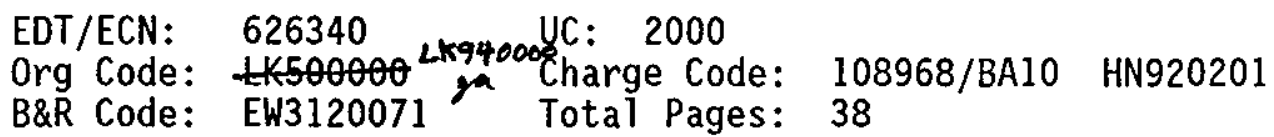

Key Words: rapid mitigation, 241-SY-101, testing \& evaluation plan, waste transfer \& dilution system, equipment

Abstract: The purpose of this testing and evaluation plan (TEP) is to provide the high level guidance on testing requirements for ensuring that the equipment and systems to be implemented for remediation of the SY-101 waste level rise USQ are effective. This TEP adresses the requirements and guidance provided in HNF-2029, "TWRS Testing and Evaluation Management Plan," HNF-IP-0842, Volume II, Section 4.1.3, "Joint Test Review Process," and HNF-IP-0842, Volume IV, Section 4.28, "Testing Practices Requirements."

TRADEMARK DISCLAIMER. Reference herein to any specific comercial product, process, or service by trade name, trademark, manufacturer, or otherwise, does not necessarily constitute or imply its endorsenent, recommendation, or favoring by the United States Government or any agency thereof or its contractors or subcontractors.

Printed in the United States of America. To obtain copies of this document, contact: HHC/BCS Document Control Services, P.O. Box 1970, Mailstop H6-08, Richland WA 99352, Phone (509) 372-2420. Fax (509) 376-4989.
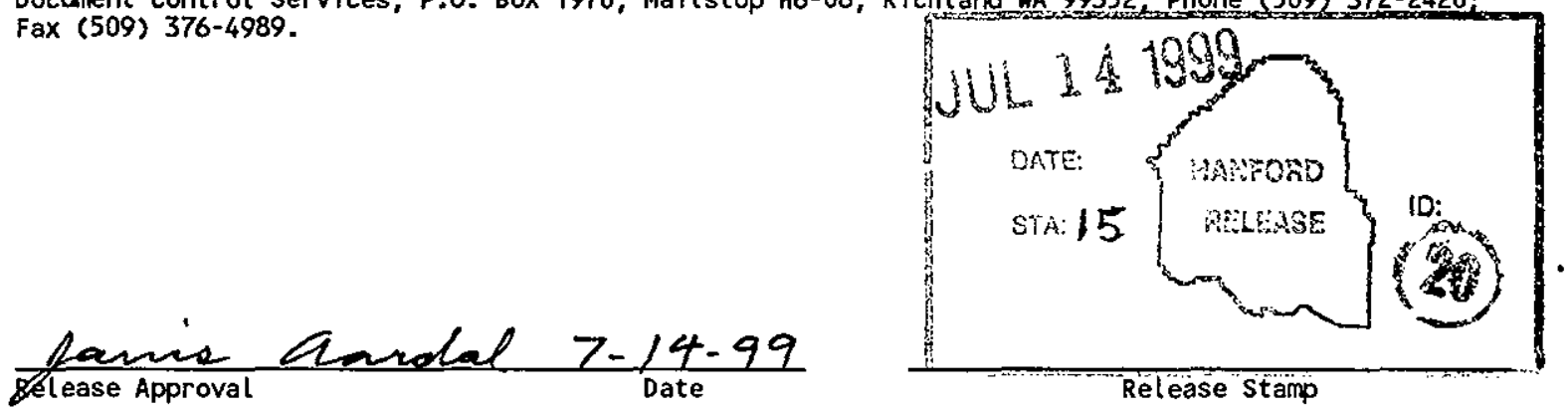

Approved for Public Release 
HNF-4410

Rev. 0

\section{Tank 241-SY-101 \\ Surface Level Rise \\ Remediation Test and \\ Evaluation Plan for \\ Transfer System}

Prepared for the U.S. Department of Energy

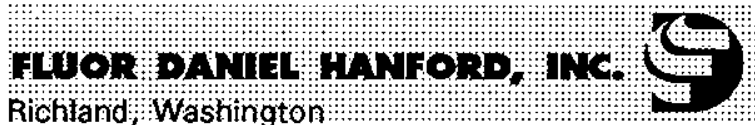

Richfand Waskington

Hanford Management and Integration Contractor for the

U.S. Department of Energy under Contract DE-AC06-96RL13200 


\section{Tank 241-SY-101 Surface Level Rise Remediation Test and Evaluation Plan for Transfer System}

R. E. Bauer

Lockheed Martin Hanford Corporation

Date Published

MAY 1999

Prepared for the U.S. Department of Energy

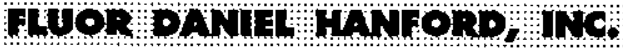

P.O. Box 1000

Richland, Washington ntegration Contractor for the

under Contract DE-ACO6-96RL13200 
LEGAL DISCLAIMER-

This report was prepared as an account of work sponsored by an agency of the United States Government. Neither the United States Government nor any agency thereof, nor any of their employees, nor any of their contractors, subcontractors or their employees, makes any warranty, express or implied, or assumes any legal liability or responsibility for the accuracy, completeness, or any third party's use or the results of such use of any information, apparatus, product, or process disclosed, or represents that its use would not infringe privately owned rights. Reference herein to any specific commercial product, process, or service by trade name, trademark, manufacturer, or otherwise, does not necessarily constitute or imply its endorsement, recommendation, or favoring by the United States Government or any agency thereof or its contractors or subcontractors. The views and opinions of authors expressed herein do not necessarily state or reflect those of the United States Government or any agency thereof.

This report has been reproduced from the best available copy.

Available in paper copy and microfiche.

Available to the U.S. Department of Energy and its contractors from

U.S. Department of Energy

Office of Scientific and Technical Information (OSTI)

P.O. Box 62

Oak Ridge, TN 37831

(615) 576-8401

Availabie to the public from the U.S. Department of Commerce

National Technical Information Service (NTIS)

5285 Port Royal Road

Springfield, VA 22161

(703) $487-4650$

Printed in the United States of America

DISCLM-1.CHP (8-95 


\section{TABLE OF CONTENTS}

1.0 PURPOSE

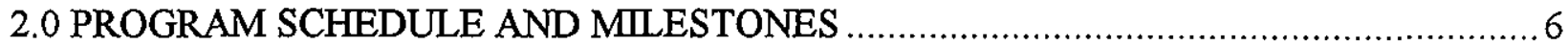

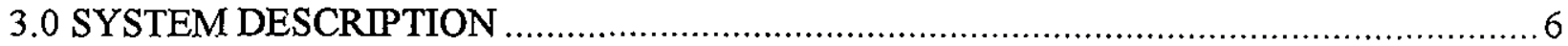

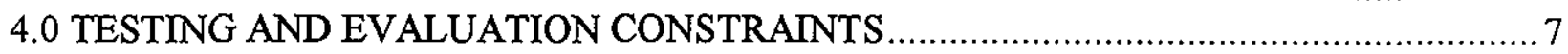

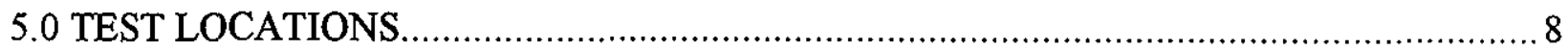

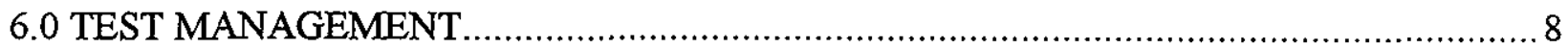

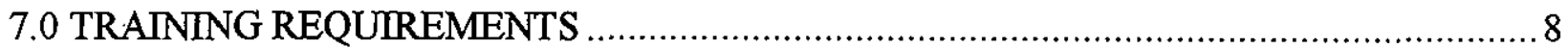

8.0 CRITICAL OPERATIONAL ISSUES FOR TESTING AND EVALUATION …................

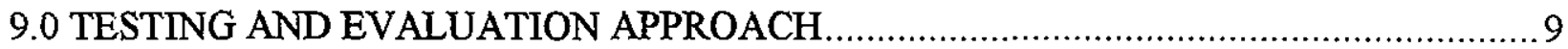

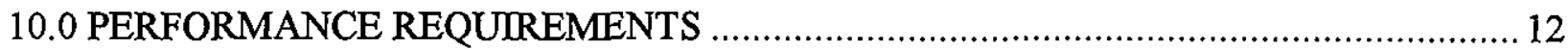

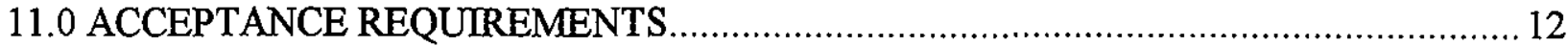

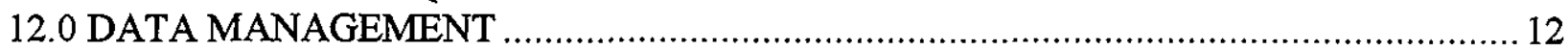

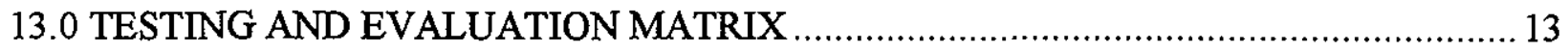

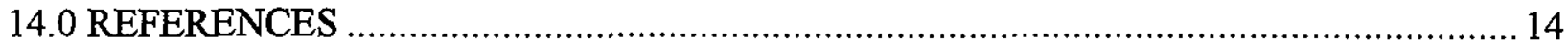

\section{FIGURES}

FIGURE 1 TRANSFER AND DILUTE SYSTEM BLOCK DIAGRAM AT MOCK-UP SITE ...15 FIGURE 2 TRANSFER AND DILUTE SYSTEM BLOCK DIAGRAM

\section{APPENDIXES}

A WAIVER OF JOINT TEST REVIEW GROUP REQUIREMENTS ……....................... 17

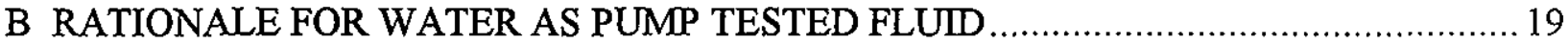

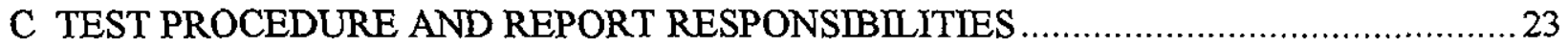




\section{LIST OF ACROYNYMS}

$\begin{array}{ll}\text { ATP } & \text { - Acceptance Test Procedure } \\ \text { ATR } & \text { - Acceptance Test Report } \\ \text { DACS } & \text { - } \text { Data Acquisition and Control System } \\ \text { gpm } & \text { - } \text { gallons per minute } \\ \text { Hp } & \text { - } \text { horse power } \\ \text { NDE } & \text { - Non-Destructive Examination } \\ \text { OTP } & \text { - Operational Test Procedure } \\ \text { OTR } & \text { - Operational Test Report } \\ \text { PPP } & \text { - Prefabricated Pump Pit } \\ \text { TEP } & \text { - Testing and Evaluation Plan } \\ \text { TWRS } & - \text { Tank Waste Remediation System } \\ \text { USQ } & \text { - Unreviewed Safety Question } \\ \text { VFD } & - \text { Variable Frequency Drive } \\ \text { WEMD } & - \text { Westinghouse Electro-Mechanical Division }\end{array}$




\section{TESTING AND EVALUATION PLAN \\ SY TRANSFER SYSTEM}

\subsection{PURPOSE}

The purpose of this testing and evaluation plan (TEP) is to provide the high level guidance on testing requirements for ensuring that the equipment and systems to be implemented for remediation of the SY-101 waste level rise USQ are effective. This TEP addresses the requirements and guidance provided in HNF-2029, "TWRS Testing and Evaluation Management Plan", HNNF-IP-0842, Volume II, Section 4.1.3, "Joint Test Review Process", and HNF-IP-0842, Volume IV, Section 4.28, "Testing Practices Requirements".

\subsection{PROGRAM SCHEDULE AND MILESTONES}

The program schedule and milestones are included in HNF-3824, "Tank 241-SY-101 SurfaceLevel-Rise Remediation Project Plan". The detailed project working schedule is maintained by the Project Manager. The required dates for delivery of the equipment for the preoperational testing and for the field installation are included in Figures 1 and 2 respectively.

\subsection{SYSTEM DESCRIPTION}

The technical approach to solve the SY-101 level rise issue by waste transfer and back dilution requires equipment to transfer waste to SY-102 and back dilute SY-101 waste with water.

The waste transfer and dilution system is comprised of a number of components and subassemblies. Major components include:

- transfer pump assembly

- prefabricated pump pit assembly

- transfer line assembly

- drop leg for SY-102

- instrumentation and control system

- utilities

Transfer Pump Assembly. The transfer pump is the central component of the waste transfer and dilution system. The pump to be used is the new generation variable frequency drive transfer pump. The design point for the $60 \mathrm{Hp}$ pump is $140 \mathrm{gpm}$ at $450 \mathrm{ft}$ of head. The variable speed capability will provide higher or lower flow and head as required. The pump is equipped with a system to in-line dilute the waste, which will be necessary to successfully accomplish the transfer.

Prefabricated Pump Pit Assembly. The prefabricated pump pit assembly supports the transfer pump in the tank and also performs the leak confinement function of a pump pit. The prefabricated pump pit is a steel structure that interfaces with Riser 007, which is one of the $1.1 \mathrm{~m}$ 
(42 in.) diameter risers. The pit positions the pump such that the inlet is approximately $2.4 \mathrm{~m}$ (eight feet) from the tank bottom and contains the valving required to accomplish routing of the waste and dilution water. The pit is equipped with a drain that will allow any liquid resulting from leaks during the transfer process to return to the tank.

Transfer Line Assembly. The transfer line assembly will be a double contained overground line.

Drop Leg for SY-102. The drop leg in SY-102 will be installed in riser 007 in SY-102. The drop leg will inject the waste approximately $4.1 \mathrm{~m}$ (160 in.) from the bottom of the tank through a siphon break arrangement.

Instrumentation and Control System. The instrumentation and control system shall allow for operation of the transfer pump and local monitoring of the transfer/dilution process. The transfer pump is controlled by a vendor-supplied variable frequency drive. The operator interface for pump control is an on-off key switch. The instrumentation will consist of sensors for transfer line pressure, transfer line flow, transfer line temperature, flush line isolation pressure, dilution line flow, service water supply manifold temperature, dilution water flow totalizer, and transfer pump operation (on/off indication). A densitometer under development by EM-50 will be installed to attempt to measure waste density and viscosity real time, but this instrument will not be used initially to control the transfer process.

The transfer system sensor outputs will be recorded by a data logger for offline analysis. This analysis will assist in tracking the waste behavior in both SY-101 and SY-102.

Control of the system will also utilize system alarms and automatic shutdown. System alarms will include leak detection, low dilution line temperature, flush water isolation pressure, low dilution water flow, high dilution water flow, and pump trip (automatic shutdown). Automatic pump shutdown will occur on loss of dilution flow or high dilution flow.

Utilities. The utilities include the electrical power required to operate the pump, electrical power required for the instrumentation, and dilution water skid. The 460V 3-phase power needed to operate the pump will be obtained from the motor control center that supplies the existing mixer pump in SY-101. The dilution water will be supplied from the existing water supply through a dilution system skid to the pump.

\subsection{TESTING AND EVALUATION CONSTRAINTS}

There are several constraints that will affect the "realism" of the planned testing. These constraints affect the preoperational and operational testing.

Preoperational testing constraints: The approach proposed for preoperational testing is to mockup the waste transfer system using components identical, to the extent practical, to those to be installed in the field. This approach is being pursued in order to optimize the schedule for system readiness by allowing installation of the field equipment in parallel with the mock-up testing. The portions of the test system that will not utilize actual system components are the 
transfer pump and the waste transfer line/drop leg. The physical interfaces and functions of these components will be simulated using surrogate equipment.

Operational testing constraints: The primary constraint with this testing is that it will not be possible to run the transfer pump as a part of this testing. The pump cannot be run because this would result in the transfer of waste from SY-101 to SY-102. Waste transfer will not be allowed until the system readiness has been assured, which includes system acceptance by Operations. The risk resulting from this constraint will be mitigated by the acceptance testing performed on the transfer pump prior to installation and by the rigor of verification of the system connections following installation.

\subsection{TEST LOCATIONS}

The proposed testing locations are listed in the Test and Evaluation Matrix, section 13.0, and are discussed in section 9.0, Testing and Evaluation Approach.

\subsection{TEST MANAGEMENT}

The project responsibilities are specified in HNF-3824. The Acceptance and Preoperational testing shall be the responsibility of the SY Project Engineering Manager. The Operational testing is the responsibility of the SY Project Manager and responsibility for the test planning and conduct will be as specified in HNF-IP-0842, Volume II, Section 4.1.3. The responsibilities for test procedures, test conduct, and test reporting are listed in Appendix C.

\subsection{TRAINING REQUIREMENTS}

The mock-up system that will be assembled to perform integrated testing is also intended to assist in operator training. The performance-based portion (at least the initial) of operator training is to be conducted using this system. Preparations for the integrated testing will also support familiarization of the craft with equipment installation. Drills for emergency preparedness and upset conditions may also be performed using this system. The initial training would be accomplished during the preoperational phase of testing. The mock-up system is expected to remain intact following completion of preoperational testing and will be available for any subsequent training or drills needed.

\subsection{CRITICAL OPERATIONAL ISSUES FOR TESTING AND EVALUATION}

The critical technical and operational issues to be addressed by the testing and evaluation will be specified in the test plans developed for each test. 


\subsection{TESTING AND EVALUATION APPROACH}

\section{Overall Testing Plan:}

The types of testing planned to support system design verification, equipment qualification, and system acceptance for operation are:

- Acceptance Testing: This testing is performed on a completed component or subsystem in order to prove that the design requirements have been met. This testing is performed using an approved test procedure and completion is documented with the Acceptance Test Report (ATR). The testing will be conducted under the direction of the Project Engineering Manager and will not be subject to the requirements of the Joint Test Group per HNF-IP-0842, Volume II, Section 4.1.3. The required waiver of this requirement is included in Appendix A. All purchased sub-systems will be tested at the vendor and have an ATR issued for them.

- Preoperational Testing: This testing is also referred to as the "Integrated Test" or "Mock-up Test". This testing is performed to demonstrate the system interfaces (physical and operational). The testing will be performed using an approved test procedure and documented with a test report. The equipment arrangement proposed for this testing is shown in Figure 1. The testing will be conducted using the TWRS Cold Test Facility. The testing will be conducted under the direction of the Project Engineering Manager and will not be subject to the requirements of the Joint Test Group per HNF-IP-0842, Volume II, Section 4.1.3. The required waiver of this requirement is included in Appendix A.

- Installation Inspection: Prior to operational testing, the equipment installed at the SY Farm shall be inspected to ensure work is completed per the design requirements. These inspections shall be performed and documented per the installation work package instructions. This activity is not governed by this plan, but is an important task to support verification of readiness for operation.

- Operational Testing: This testing will be performed following installation of the equipment in the SY farm. This testing will be conducted using an Operational Test Procedure (OTP) per HNF-IP-0842, Volume IV, Section 4.28. The OTP will be conducted under the direction of the Joint Test Group per HNF-IP-0842, Volume II, Section 4.1.3. The equipment configuration proposed for this testing is shown in Figure 2.

For testing other than that performed as a part of a procurement, test documents and reports shall be prepared, reviewed, approved, controlled, and modified in accordance with HNF-IP-0842, Volume IV, Section 4.28 as baseline documents.

In the case of testing performed by vendors as a part of a procurement activity, the test procedure documentation, review, and approval shall be as specified by the procurement contract. Since the test procedures generated by this process are procurement records and not controlled as 
"supporting documents," these test procedures are to be included, in full, in the final acceptance test report in order to enhance retrievability.

The major components for the system and the testing planned are listed in the Testing and Evaluation Matrix (see Section 13.0). The following is a brief summary of each piece of equipment and the testing/installation plans.

\section{Planned Testing for System Components:}

- Transfer Pump-1: This is the existing transfer pump manufactured and tested by WEMD. The pump will be transported to Sulzer-Bingham, Portland, Oregon for modification and testing. Testing following modification will include inspection (dimensional, NDE, etc.) to ensure that the modifications meet the design specifications. This testing is probably more accurately called "inspection" and will be documented in an ATR.

Following modification, the "run-in" acceptance test will be performed. The purpose of this test will be to run the pump long enough to ensure that the pump is still functional after the long storage period and to test the dilution flow system. This testing will be done in water. Testing using water as the waste simulant is recognized and accepted by the project as a technical risk. The technical risk is due to pump performance issues associated with higher than expected viscosity, potential plugging of small internal passages, and lack of tank farm experience with this type of pump. The rationale for selecting water as the test fluid is included as Appendix B.

Following installation into SY-101, the pump will be included in the operational testing, however it is not anticipated that the pump will be operated as a part of this test (as discussed in section 4.0).

- Transfer Pump-2 (On order): This testing will be acceptance testing specified by the procurement specification with WEMD.

- VFD-1: This device will be tested in conjunction with Transfer Pump-1.

- VFD-2: This testing will be that specified by the procurement specification with the vendor.

- Prefabricated Pump Pit-1: The prefabricated pump pit consists of the Box and the Valving/Instrumentation manifold. The design/build contractor prior to shipment to TWRS will perform the acceptance testing of this equipment. This equipment will undergo operational testing after installation at SY-101.

- Prefabricated Pump Pit-2: The prefabricated pump pit consists of the Box and the Valving/Instrumentation manifold. The design/build contractor prior to shipment to TWRS will perform the acceptance testing of this equipment. This equipment will undergo further testing during the Integrated Test at the Cold Test Facility. Following the Integrated Test this equipment will remain at the Cold Test Facility to assist any 
additional operator training. This equipment is also the spare parts for this portion of the transfer system.

- PPP Instrument Rack-1: This subsystem provides the electrical power and signal conditioning for the instrumentation needed for the transfer system. This system also contains the power disconnect for use in automatic shutdown of the pump. The design/build contractor prior to shipment to TWRS will perform the acceptance testing of this equipment. This equipment will undergo operational testing after installation at SY-101.

- PPP Instrument Rack-2: This subsystem provides the electrical power and signal conditioning for the instrumentation needed for the transfer system. This system also contains the power disconnect for use in automatic shutdown of the pump. The design/build contractor prior to shipment to TWRS will perform the acceptance testing of this equipment. This equipment will undergo further testing during the Integrated Test at the Cold Test Facility. Following the Integrated Test this equipment will remain at the Cold Test Facility to assist any additional operator training. This equipment is also the spare parts for this portion of the transfer system.

- Water Skid-1: The water skid provides the dilution water and control system for the dilution supply and line flush to the transfer pump. The design/build contractor prior to shipment to TWRS will perform the acceptance testing of this equipment. This equipment will undergo operational testing after installation at SY-101.

- Water Skid-2: The water skid provides the dilution water and control system for the dilution supply and line flush to the transfer pump. The design/build contractor prior to shipment to TWRS will perform the acceptance testing of this equipment. This equipment will undergo further testing during the Integrated Test at the Cold Test Facility. Following the Integrated Test this equipment will remain at the Cold Test Facility to assist any additional operator training. This equipment is also the spare parts for this portion of the transfer system.

- Valve Stand -1: This system Provides the flow regulation, flowmeter, and pressure transducer for the dilution water supply. The design/build contractor prior to shipment to TWRS will perform the acceptance testing of this equipment. This equipment will undergo operational testing after installation at SY-101.

- Valve Stand -2 : This system Provides the flow regulation, flowmeter, and pressure transducer for the dilution water supply. The design/build contractor prior to shipment to TWRS will perform the acceptance testing of this equipment. This equipment will undergo further testing during the Integrated Test at the Cold Test Facility. Following the Integrated Test this equipment will remain at the Cold Test Facility to assist any additional operator training. This equipment is also the spare parts for this portion of the transfer system.

- Instrumentation Rack-1 for DACS: This panel is located in the DACS trailer and is the primary operator interface for control of the transfer system. The design/build contractor 
prior to shipment to TWRS will perform the acceptance testing of this equipment. This equipment will undergo operational testing after installation at SY-101.

- Instrumentation Rack-2 for DACS: This panel is located in the DACS trailer and is the primary operator interface for control of the transfer system. The design/build contractor prior to shipment to TWRS will perform the acceptance testing of this equipment. This equipment will undergo further testing during the Integrated Test at the Cold Test Facility. Following the Integrated Test this equipment will remain at the Cold Test Facility to assist any additional operator training. This equipment is also the spare parts for this portion of the transfer system.

- Overground Transfer Line: This is the transfer line and encasement that routes the waste from the PPP to the drop leg. The acceptance testing of this equipment will be performed at the fabrication shop prior to shipment to SY-101. This equipment will undergo operational testing after installation at SY-101.

- Drop Leg: This is the portion of the transfer line that protrudes into SY-102 to direct the waste to the desired location in the tank. The acceptance testing of this equipment will be performed at the fabrication shop prior to shipment to SY-101. This equipment will undergo operational testing after installation at SY-101.

\subsection{PERFORMANCE REQUIREMENTS}

The performance requirements to be addressed by the testing and evaluation will be specified in the test procedures developed for each test.

\subsection{ACCEPTANCE REQUIREMENTS}

The acceptance requirements to be met by the testing and evaluation will be specified in the test procedures developed for each test.

\subsection{DATA MANAGEMENT}

All data generated by the testing shall be documented and maintained per the requirements of HNF-IP-0842, Volume IV, Section 4.28. 


\subsection{TESTING AND EVALUATION MATRIX}

\begin{tabular}{|c|c|c|c|c|c|}
\hline EQUIPMENT & $\begin{array}{l}\text { EQUTPMENT } \\
\text { SOURCE }\end{array}$ & $\begin{array}{c}\text { ACCEPTANCE } \\
\text { TESTING } \\
\text { LOCATION } \\
\end{array}$ & $\begin{array}{c}\text { PRE- } \\
\text { OPERATIONAL } \\
\text { TESTING } \\
\end{array}$ & $\begin{array}{c}\text { FINAL } \\
\text { DESTINATION }\end{array}$ & $\begin{array}{l}\text { OPERATIONAL } \\
\text { TESTING }\end{array}$ \\
\hline Transfer Pump-1 & $\begin{array}{l}\text { Existing in } \\
2101-\mathrm{M}\end{array}$ & $\begin{array}{l}\text { Sulzer Bingham, } \\
\text { Portland, OR } \\
\text { "Pump Run in" }\end{array}$ & No & SY-101 & Yes \\
\hline $\begin{array}{l}\text { Transfer Pump-2 } \\
\text { (On order) }\end{array}$ & $\begin{array}{l}\text { Westinghouse } \\
\text { Electro- } \\
\text { Mechanical } \\
\text { Division, } \\
\text { Pittsburgh, PA } \\
\text { (WEMD) }\end{array}$ & WEMD & No & $\begin{array}{c}\text { 2101-M } \\
\text { Spare Parts }\end{array}$ & No \\
\hline VFD-1 & $\begin{array}{l}\text { Existing in } \\
2101-M\end{array}$ & $\begin{array}{l}\text { Sulzer Bingham, } \\
\text { Portland, OR } \\
\text { "Pump Run in" }\end{array}$ & Yes & $\begin{array}{c}\text { 2101-M } \\
\text { Spare Parts }\end{array}$ & No \\
\hline VFD-2 & $\begin{array}{l}\text { Robicon, } \\
\text { George Koley } \\
\text { Engineering, } \\
\text { Issaquah, WA }\end{array}$ & $\begin{array}{l}\text { Sulzer-Bingham, } \\
\text { Portland, OR "Pump } \\
\text { Run-In" }\end{array}$ & No & SY-101 & Yes \\
\hline $\begin{array}{l}\text { Prefab. Pump } \\
\text { Pit-1 (PPP-1) }\end{array}$ & $\begin{array}{l}\text { Design/Build } \\
\text { Contract }\end{array}$ & Contractor & See Below & See Below & See Below \\
\hline Box-1 & & & No & SY-101 & Yes \\
\hline $\begin{array}{l}\text { Piping/valving/in } \\
\text { st-1 }\end{array}$ & & & No & SY-101 & Yes \\
\hline $\begin{array}{l}\text { Prefab. Pump } \\
\text { Pit-2 (PPP-2) }\end{array}$ & $\begin{array}{l}\text { Design/Build } \\
\text { Contract }\end{array}$ & Contractor & See Below & See Below & See Below \\
\hline Box-2 & & & Yes & $\begin{array}{c}\text { Cold Test } \\
\text { Facility/Spare } \\
\text { Parts }\end{array}$ & No \\
\hline $\begin{array}{l}\text { Piping/valving/in } \\
\text { st-2 }\end{array}$ & & & Yes & $\begin{array}{c}\text { Cold Test } \\
\text { Facility/Spare } \\
\text { Parts } \\
\end{array}$ & No \\
\hline $\begin{array}{l}\text { PPP Instrument } \\
\text { Rack-1 }\end{array}$ & $\begin{array}{l}\text { Design/Build } \\
\text { Contract }\end{array}$ & Contractor & No & SY-101 & Yes \\
\hline $\begin{array}{l}\text { PPP Instrument } \\
\text { Rack-2 }\end{array}$ & $\begin{array}{l}\text { Design/Build } \\
\text { Contract }\end{array}$ & Contractor & Yes & $\begin{array}{c}\text { Cold Test } \\
\text { Facility/Spare } \\
\text { Parts } \\
\end{array}$ & No \\
\hline Valve Stand - 1 & $\begin{array}{l}\text { Design/Build } \\
\text { Contract } \\
\end{array}$ & Contractor & No & SY-101 & Yes \\
\hline Valve Stand - 2 & $\begin{array}{l}\text { Design/Build } \\
\text { Contract }\end{array}$ & Contractor & Yes & $\begin{array}{c}\text { Cold Test } \\
\text { Facility/Spare } \\
\text { Parts } \\
\end{array}$ & No \\
\hline Water Skid-1 & $\begin{array}{l}\text { Design/Build } \\
\text { Contract } \\
\end{array}$ & Contractor & No & SY-101 & Yes \\
\hline Water Skid-2 & $\begin{array}{l}\text { Design/Build } \\
\text { Contract }\end{array}$ & Contractor & Yes & $\begin{array}{c}\text { Cold Test } \\
\text { Facility/Spare } \\
\text { Parts }\end{array}$ & No \\
\hline
\end{tabular}


Rev. 0

\begin{tabular}{|l|l|l|c|c|c|}
\hline $\begin{array}{l}\text { Instrumentation } \\
\text { Rack-1 for } \\
\text { DACS }\end{array}$ & $\begin{array}{l}\text { Design/Build } \\
\text { Contract }\end{array}$ & Contractor & No & SY-101 & Yes \\
\hline $\begin{array}{l}\text { Instrumentation } \\
\text { Rack-2 for } \\
\text { DACS }\end{array}$ & $\begin{array}{l}\text { Design/Build } \\
\text { Contract }\end{array}$ & Contractor & Yes & $\begin{array}{c}\text { Cold Test } \\
\text { Facility/Spare } \\
\text { Parts }\end{array}$ & No \\
\hline $\begin{array}{l}\text { Overground } \\
\text { Transfer Line }\end{array}$ & $\begin{array}{l}\text { Fabrication } \\
\text { Services }\end{array}$ & Fab. Shops & No & SY-101 & Yes \\
\hline Drop Leg & $\begin{array}{l}\text { Fabrication } \\
\text { Services }\end{array}$ & Fab. Shops & No & SY-101 & Yes \\
\hline
\end{tabular}

\subsection{REFERENCES}

HNF-2029, "TWRS Testing and Evaluation Management Plan"

HNF-3824, "Tank 241-SY-101 Surface-Level-Rise Remediation Project Plan"

HNF-3825, Rev. 1, "Specification for the Tank Farms Transfer Pumps with Submersible Motors"

HNF-4043, "Specification for SY-101 Rapid Mitigation Mobile Water Support Skid"

HNF-4169, "Specification for SY-101 Rapid Mitigation Prefabricated Pump Pit"

HNF-4170, "Specification for SY-101 Rapid Mitigation Transfer Pump Piping"

HNF-4185, Rev. 0A, "Specification for Variable Frequency Drive"

HNF-4186, Rev. 1, "Specification for New Generation Transfer Pump Test"

HNF-4216,"Specification for the SY-101 Rapid Mitigation System Anti-Siphoning Slurry

Distributor Assembly"

HNF-4235, "Specification of SY-101 Rapid Mitigation Transfer Pump I\&C Enclosures"

HNF-4407, "Specification for the SY-101 Rapid Mitigation System Hose and Hose Assembly"

HNF-IP-0842, Volume II, Section 4.1.3, "Joint Test Review Process"

Volume IV, Section 4.28, "Testing Practices Requirements" 
最高

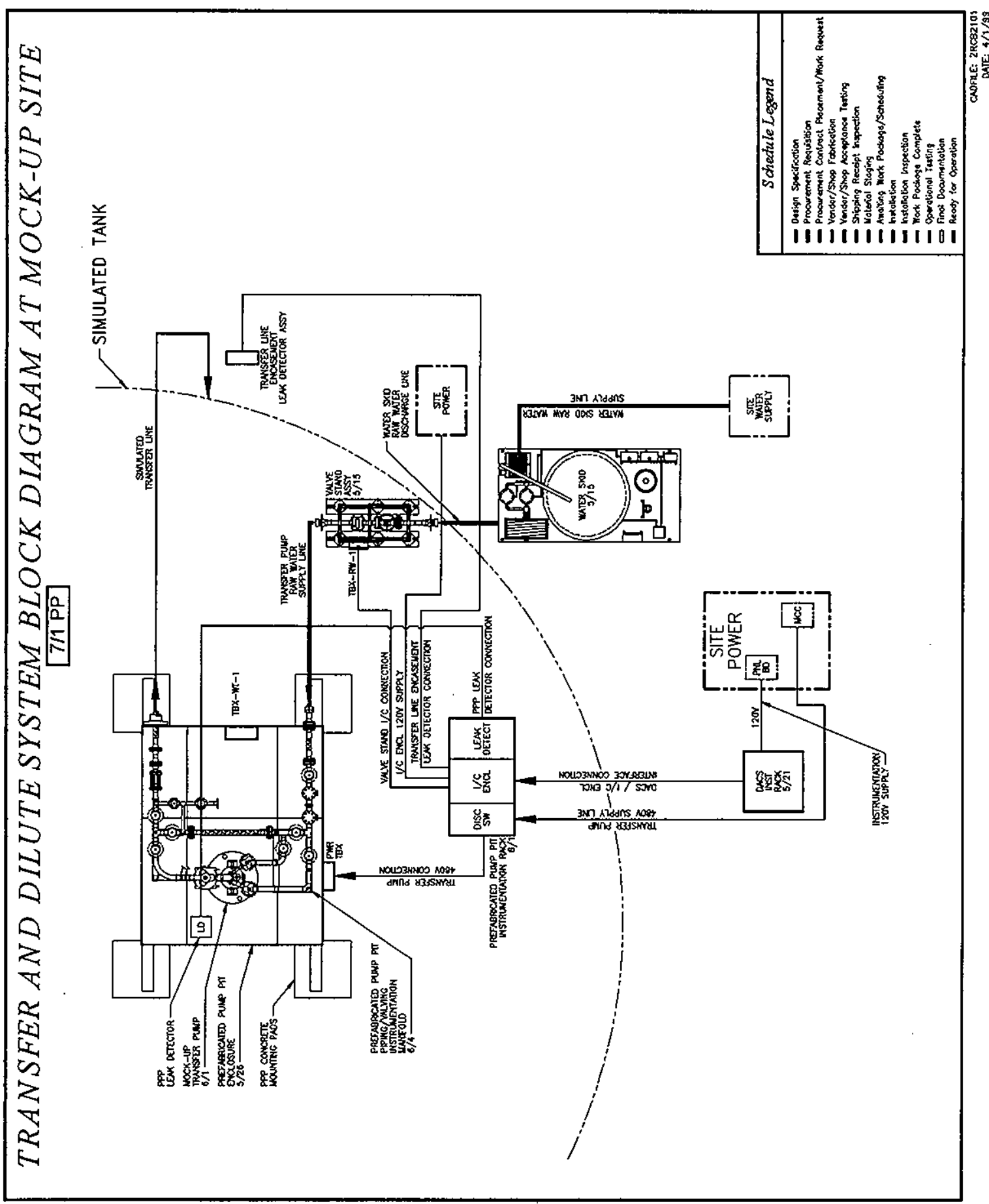




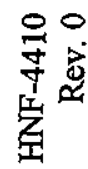

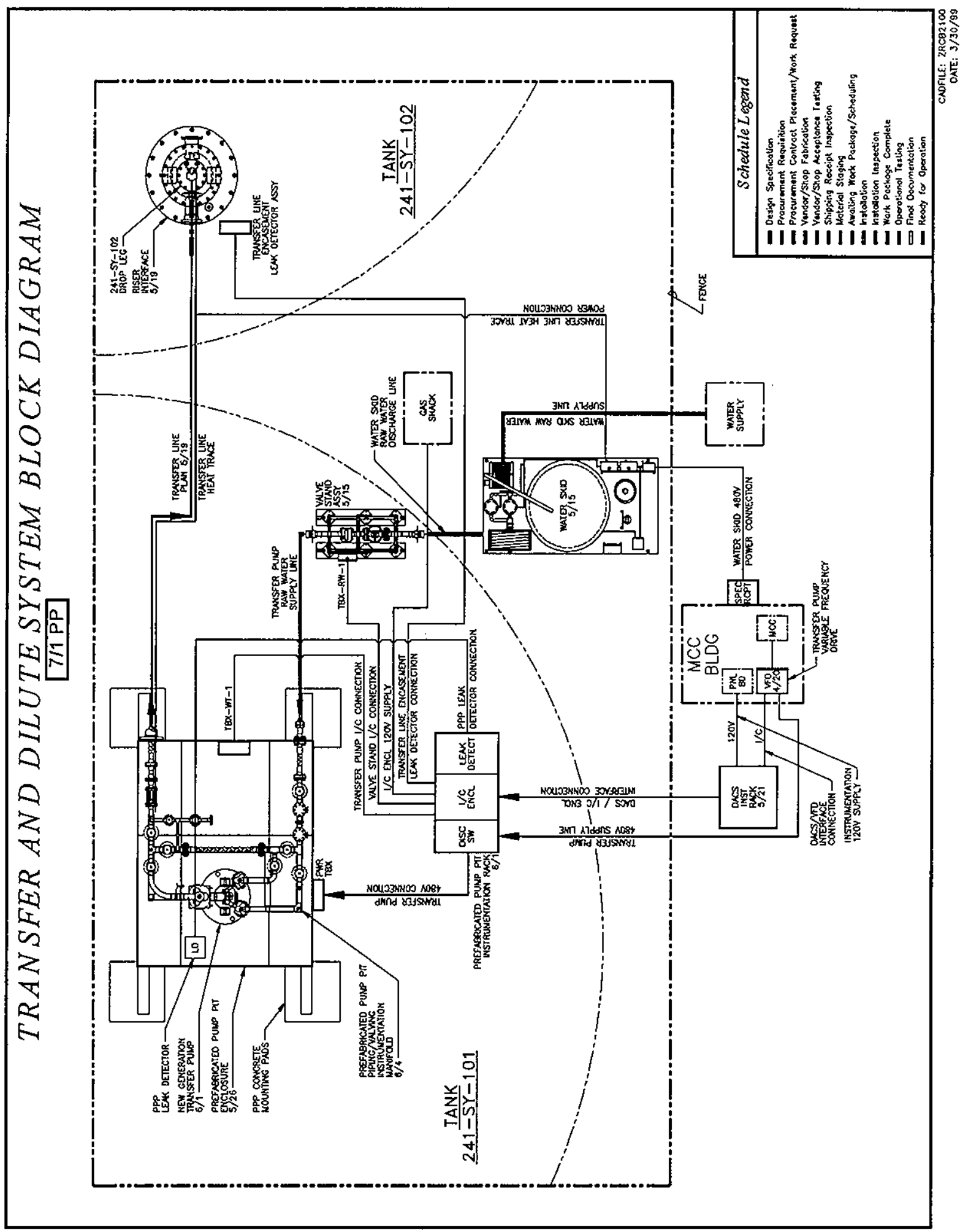


Rev. 0

APPENDIX A

WAIVER OF JOINT TEST REVIEW GROUP REQUIREMENTS 
MEMORANDUM FROM:TWRS Testing and Systems Readiness Manager SUBJECT: Authorization for testing

1. The following testing was previously underway and may be continued

2. The following testing is exempted from "Testing Oversight Review" All SY-101 component and subsystem-Acceptance and Preoperational Testing associated with surface Level Rise Remediation transfer system.

Transfer Pump 1-operational Testing

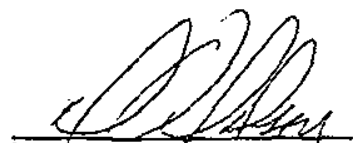

ThRS Testing and System Readiness Manager

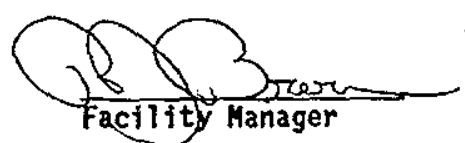


APPENDIX B

RATIONALE FOR WATER AS PUMP TEST FLUID

CE HANSON

KL MORRIS

FM HAUCK 
To:

From:

File

Carl Hanson

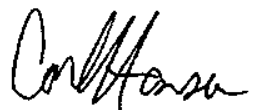

Subject:

\section{SIMULANT TESTING FOR WESTINGHOUSE ELECTROMECHANICAL DNISION NEW GENERATION TRANSFER PUMP}

\section{Cc: TL Benegas FM Hauck KL Morris CEH/lbf}

Date: April 1, 1999

Attached please find a copy of a "white paper", which discusses design engineering's position, regarding the rationale for not testing the New Generation Transfer Pump (NGTP) with simulant, prior to deployment in tank 241-SY-101. This pump will be used to pump waste from SY-101 to SY-102, as a means of addressing the crust level growth issue in SY-101. 
Alternative Evaluation (Trade Study) for Water Tests or Simulant Tests on SY-101 Transfer Pump.

Introduction

The 241-SY-101 remediation path forward includes transfer of 100.00 to 150,000 gallons of waste from 241-SY-101 to 241-SY-102 by fall of 1999. The New Generation Transfer Pump ((NGTP), which meets all safety and mission requirements, has been chosen. This pump had been procured for a similar use, but not this exact application.

The NGTP is a $60 \mathrm{hp}$, variable frequency drive, centrifugal pump with a canned motor design. Its design point is $140 \mathrm{gpm}$ at $450 \mathrm{ft}$ of head with capability to operate at lower and higher flow rates and head.

Standard Testing

The normal test fluid for Hanford transfer and mixer pumps has been water. This testing follows the standard practice for centrifugal pump testing (ANSI, American National Standard for Centrifugal Pump Tests, ANSI/HI-2.6, Hydraulic Institute, Parsippany, New Jersey). Testing the NGTP with an alternate fluid has been under consideration. Should the actual fluid differ, information on pumping capability can be gathered from data tables and mathematical relations available in hydraulic handbooks and manuals (Hydraulic Institute Standards, Cameron Hydraulic Data and others).

The pump manufacturer, Westinghouse Electro-Mechanical Division (WEMD), performed simulant testing on the bearing materials for wear and erosion along with testing the flushing system to determine that settled solids would flush out of the pump. The results of this testing were used to determine the final design configurations.

Mixer and transfer pumps have been successfully operated at the site after testing in water. The most significant of these has been the mixer pump in 241-SY-101, that has successfully operated since 1994 in the undiluted waste. It was tested solely in water. Of note, the NGTP will initially be transferring diluted waste at a 1:1 dilution ratio (or higher with water). This places the fluid characteristics for the transfer pump at close to those for which it was originally designed. It was designed to pump fluid with a specific gravity of 1.5 and a viscosity of 30 centipoise. Also, the manufacturer of the pump, WEMD, has rerun all of their analyses to determine how the pump will perform if subjected to higher viscosity fluids. Preliminary results indicate that the pump will provide sufficient head and flow at viscosities up to 300 centipoise.

\section{Additional Testing Issues}

The following points have been raised regarding the use of simulants for testing and each can be closed either with good engineering judgement based on many years of experience or by other means of gathering the information (e.g., modeling).

1. Simulating dilution mixing of $1 \mathrm{SpG}$ fluid with $1.7 \mathrm{SpG}$ fluid. This was discussed both with PNNL and the pump manufacturer. The pump is very stout and the differences in specific gravity should not cause undue wear on the pump or cause the pump to operate outside its design limits. The 10,000 -hour/10 year design life of the pump is based on full speed operation with a very abrasive 
pumpage. This specific application will be at a much lower speed that will result in a significantly extended life.

2. Simulating slurry transfer. A slurry simulant, to be effective, must either be three simulants (as listed below) or have all the three characteristics listed below in one simulant. Such a simulant has not been developed although three may be available.

- Simulant exhibiting high specific gravity (1.7)

- Simulant exhibiting high viscosity ( $\sim 600 \mathrm{cP}$ with or without shear thinning)

- Simulant exhibiting worst case plugging characteristics (sticky simulant or large particles)

Viscosity is difficult to mimic, but can be modeled for worst case. Specific gravity, $\mathrm{SpG}$ is believed to be unnecessary (see Item 1). Plugging should not be an issue; the pump manufacturer, WEMD, tested plugging and the results discussed in Chapter 12 of the Design Report. Computer modeling of high viscosity is being performed under a contract with WEMD. Current parameters for the transfer (1:1 dilution and 60-gpm flow through the pump result in about a $1.3 \mathrm{SpG}$ and $30 \mathrm{cP}$ waste characteristics) fall within the original design specification of the pump.

3. Plugging by wire. Wire debris has been discussed as a form of large particle that could get through the 0.25 " screen. Aside from failure testing of the pump (e.g. have it suck up sires until it cannot pump any longer), simulant testing is not recommended. The effect of long, thin debris will be minimized by the current placement of the pump at eight feet above the tank bottom and relatively low suction velocity.

\section{Conclusion and Recommendation}

Based on the significant knowledge and maturity of the pumping industry, simulant testing is not necessary. The pumpability issues unique to this application will be addressed through modeling extrapolated information from the water testing. Simulant testing would always be of interest, however it will not be necessary in this application. 


\title{
APPENDIX C
}

\section{TEST PROCEDURE AND REPORT RESPONSIBILITIES}

\author{
Preparation, Review, Approval and Performance
}




\begin{tabular}{|c|c|c|c|c|c|c|c|}
\hline \multicolumn{2}{|c|}{ EQUTP } & $\begin{array}{l}\text { TRANSFER } \\
\text { PUMP } \\
\text { 1/VFD } 1 \text { \& } 2\end{array}$ & $\begin{array}{l}\text { TRANSFER } \\
\text { PUMP } \\
\text { 1/VFD 1 \& 2 }\end{array}$ & N/A & N/A & $\begin{array}{l}\text { TRANSFER } \\
\text { PUMP } \\
\text { 1/VFD-2 }\end{array}$ & $\begin{array}{c}\text { TRANSFER } \\
\text { PUMP } \\
\text { 1/VFD-2 }\end{array}$ \\
\hline \multicolumn{2}{|c|}{ AUTHOR } & $\begin{array}{c}\text { SULZER } \\
\text { BINGHAM }\end{array}$ & $\begin{array}{c}\text { KIM } \\
\text { MORRIS }\end{array}$ & $\mathrm{N} / \mathrm{A}$ & $\mathrm{N} / \mathrm{A}$ & $\begin{array}{c}\text { KEITH } \\
\text { WTWWER }\end{array}$ & $\begin{array}{c}\text { KEITH } \\
\text { WITWER }\end{array}$ \\
\hline \multicolumn{2}{|c|}{ DOCUMENT NO } & P.O. 3680 & HNF-4359 & & & TBD & TBD \\
\hline \multicolumn{2}{|c|}{ DUE DATE } & $4 / 21 / 99$ & $5 / 14 / 99$ & & & $6 / 18 / 99$ & $7 / 28 / 99$ \\
\hline \multirow{7}{*}{ 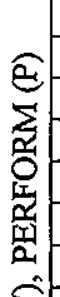 } & PROJ MGR & & & & & & \\
\hline & DES MGR & $\mathrm{A}$ & A & & & A & $\mathrm{A}$ \\
\hline & DES AGENT & $\mathrm{A}, \mathrm{W}$ & A & & & $\mathrm{A}$ & $\bar{A}$ \\
\hline & DES AUTH & $\mathrm{A}$ & $\mathrm{A}$ & & & $\mathrm{A}$ & $\mathrm{A}$ \\
\hline & COG MGR & A & A & & & A & A \\
\hline & COG ENGR & A & A & & & $\mathrm{A}$ & $\mathrm{A}$ \\
\hline & QA & $\mathrm{A}, \mathrm{W}$ & A & & & $\mathrm{A}, \mathrm{W}$ & $\mathrm{A}$ \\
\hline \multirow{3}{*}{ है } & SAFETY & & & & & & \\
\hline & NS \& L & & & & & & \\
\hline & ENVIR & & & & & & \\
\hline \multirow{3}{*}{. } & OPS & & & & & $\mathrm{A}, \mathrm{P}$ & $\bar{A}$ \\
\hline & VENDOR & $P$ & & & & & \\
\hline & JTRG & & & & & $\mathrm{A}$ & \\
\hline \multicolumn{8}{|c|}{$\begin{array}{l}4 \\
0\end{array}$} \\
\hline \multirow{2}{*}{\multicolumn{8}{|c|}{ 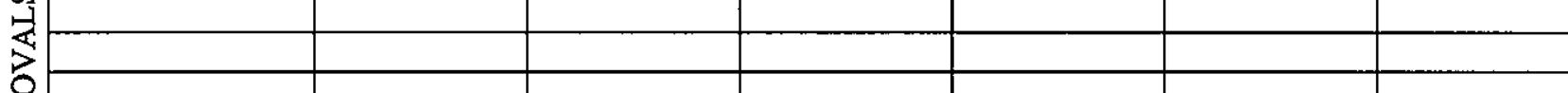 }} \\
\hline & & & & & & & \\
\hline \multirow{2}{*}{, } & & & & & & & \\
\hline & & & & & & & \\
\hline
\end{tabular}




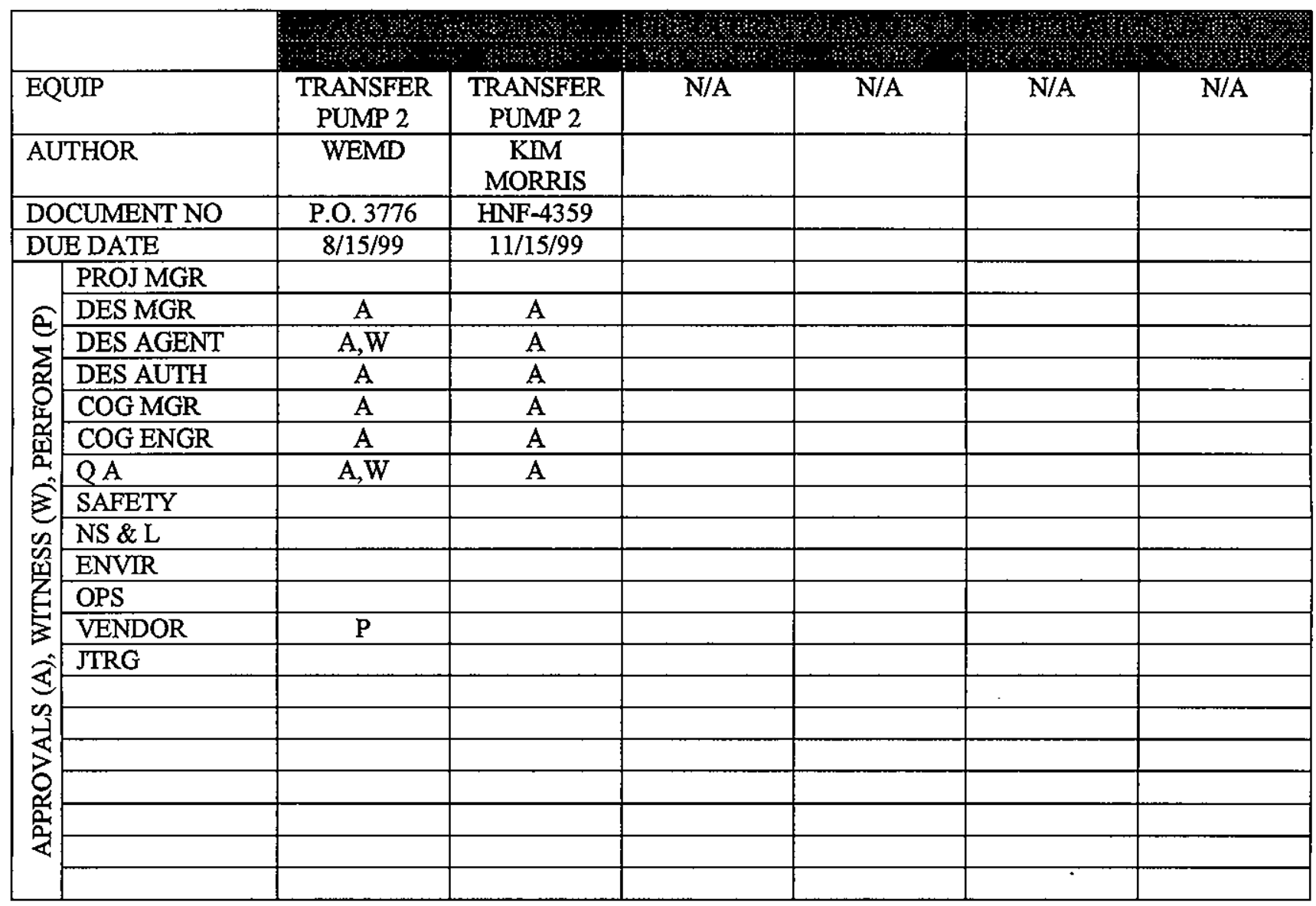




\begin{tabular}{|c|c|c|c|c|c|c|c|}
\hline \multicolumn{2}{|c|}{ EQUIP } & $\begin{array}{c}\text { PREFABRI } \\
\text { CATED } \\
\text { PUMP PIT } \\
\text { BOX-1 }\end{array}$ & $\begin{array}{l}\text { PREFABRI } \\
\text { CATED } \\
\text { PUMP PIT } \\
\text { BOX-1 } \\
\end{array}$ & $\mathrm{N} / \mathrm{A}$ & N/A & $\begin{array}{l}\text { PREFABRI } \\
\text { CATED } \\
\text { PUMP PIT } \\
\text { BOX-1 }\end{array}$ & $\begin{array}{l}\text { PREFABRI } \\
\text { CATED } \\
\text { PUMP PIT } \\
\text { BOX-1 }\end{array}$ \\
\hline \multicolumn{2}{|c|}{ AUTHOR } & OLYMPIC & $\begin{array}{c}\text { JOE } \\
\text { BUCHANAN }\end{array}$ & & & $\begin{array}{c}\text { KEITH } \\
\text { WITWER }\end{array}$ & $\begin{array}{c}\text { KEITH } \\
\text { WITWER }\end{array}$ \\
\hline \multicolumn{2}{|c|}{ DOCUMENT NO } & P.O. 3561 & HNF-4359 & & & TBD & TBD \\
\hline \multicolumn{2}{|c|}{ DUE DATE } & $4 / 16 / 99$ & $6 / 15 / 99$ & & & $6 / 18 / 99$ & $7 / 28 / 99$ \\
\hline & PROJ MGR & & & & & & \\
\hline & DES MGR & & $\mathrm{A}$ & & & $\mathrm{A}$ & $\bar{A}$ \\
\hline & DES AGENT & $\mathrm{A}, \mathrm{W}$ & $\mathrm{A}$ & & & $\mathrm{A}$ & $\mathrm{A}$ \\
\hline & DES AUTH & $\mathrm{A}$ & $\mathrm{A}$ & & & $\mathrm{A}$ & A \\
\hline & $\begin{array}{l}\text { COG MGR } \\
\end{array}$ & & A & & & $\mathrm{A}$ & $\mathrm{A}$ \\
\hline & COG ENGR & $\mathrm{A}$ & A & & & $\mathrm{A}$ & $\mathrm{A}$ \\
\hline & QA & $\mathrm{A}, \mathrm{W}$ & A & & & $\mathrm{A}, \mathrm{W}$ & $\mathrm{A}$ \\
\hline \multirow{3}{*}{ 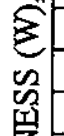 } & SAFETY & & & & & & \\
\hline & NS \& L & & & & & & \\
\hline & ENVIR & & & & & & \\
\hline \multirow{3}{*}{, } & OPS & & & & & A,P & A \\
\hline & VENDOR & $\mathrm{P}$ & & & & & \\
\hline & JTRG & & & & & $\mathrm{A}$ & \\
\hline \multirow{5}{*}{ 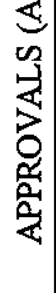 } & & & & & & & \\
\hline & & & & & & & \\
\hline & & & & & & & \\
\hline & & & & & & & \\
\hline & & & & & & & \\
\hline
\end{tabular}




\begin{tabular}{|c|c|c|c|c|c|c|c|}
\hline \multicolumn{2}{|c|}{$\overline{\text { EQUIP }}$} & $\begin{array}{c}\text { PREFABRI } \\
\text { CATED } \\
\text { PUMP PIT } \\
\text { BOX-2 }\end{array}$ & $\begin{array}{c}\text { PREFABRI } \\
\text { CATED } \\
\text { PUMP PIT } \\
\text { BOX-2 }\end{array}$ & $\begin{array}{c}\text { PREFABRI } \\
\text { CATED } \\
\text { PUMP PIT } \\
\text { BOX-2 }\end{array}$ & $\begin{array}{l}\text { PREFABRI } \\
\text { CATED } \\
\text { PUMP PIT } \\
\text { BOX-2 }\end{array}$ & N/A & N/A \\
\hline \multicolumn{2}{|c|}{ AUTHOR } & OLYMPIC & $\begin{array}{c}\text { JOE } \\
\text { BUCHANAN }\end{array}$ & $\begin{array}{c}\text { KEITH } \\
\text { WITWER }\end{array}$ & $\begin{array}{c}\text { KEITH } \\
\text { WITWER }\end{array}$ & & \\
\hline \multicolumn{2}{|c|}{ DOCUMENT NO } & P.0.3561 & HNF-4359 & TBD & TBD & & \\
\hline \multirow{2}{*}{\multicolumn{2}{|c|}{$\begin{array}{l}\text { DUE DATE } \\
\text { / PROI MGR }\end{array}$}} & $4 / 16 / 99$ & $6 / 15 / 99$ & $6 / 4 / 99$ & $7 / 28 / 99$ & & \\
\hline & & & & & & & \\
\hline \multirow{6}{*}{ 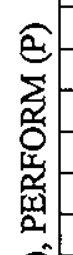 } & DES MGR & & $\mathrm{A}$ & $\mathrm{A}$ & $\mathrm{A}$ & & \\
\hline & DES AGENT & $\mathrm{A}, \mathrm{W}$ & $\mathrm{A}$ & $\mathrm{A}$ & $\mathrm{A}$ & & \\
\hline & DES AUTH & A & A & A & $\mathrm{A}$ & & \\
\hline & COG MGR & & $\overline{\mathrm{A}}$ & $\bar{A}$ & $\bar{A}$ & & \\
\hline & COGENGR & $\mathrm{A}$ & $\mathrm{A}$ & $\mathrm{A}$ & $\mathrm{A}$ & & \\
\hline & QA & $\mathrm{A}, \mathrm{W}$ & $\mathrm{A}$ & $\mathrm{A}, \mathrm{W}$ & $\mathrm{A}$ & & \\
\hline \multirow{3}{*}{$\begin{array}{l}\hat{E} \\
\mathscr{w} \\
\tilde{y} \mathbf{y}\end{array}$} & SAFETY & & & & & & \\
\hline & NS \& L & & & & & & \\
\hline & ENVIR & & & & & & \\
\hline \multirow{3}{*}{. } & OPS & & & $\mathrm{A}, \mathrm{P}$ & $\mathrm{A}$ & & \\
\hline & VENDOR & $\mathrm{P}$ & & & & & \\
\hline & JTRG & & & & & & \\
\hline ¿ & & & & & & & \\
\hline 安 & & & & & & & \\
\hline \multicolumn{8}{|l|}{. } \\
\hline \multirow{3}{*}{ 安 } & & & & & & & \\
\hline & & & & & & & \\
\hline & & & & & & & \\
\hline
\end{tabular}




\begin{tabular}{|c|c|c|c|c|c|c|c|}
\hline \multicolumn{2}{|c|}{ EQUIP } & $\begin{array}{c}\text { PREFABRI } \\
\text { CATED } \\
\text { PUMP PIT } \\
\text { MANIFOLD } \\
-1\end{array}$ & $\begin{array}{c}\text { PREFABRI } \\
\text { CATED } \\
\text { PUMP PIT } \\
\text { MANIFOLD } \\
-1\end{array}$ & N/A & N/A & $\begin{array}{c}\text { PREFABRI } \\
\text { CATED } \\
\text { PUMP PIT } \\
\text { MANIFOLD } \\
-1\end{array}$ & $\begin{array}{c}\text { PREFABRI } \\
\text { CATED } \\
\text { PUMP PIT } \\
\text { MANIFOLD } \\
-1\end{array}$ \\
\hline \multicolumn{2}{|c|}{ AUTHOR } & APOOLLO & $\begin{array}{c}\text { JOE } \\
\text { BUCHANAN }\end{array}$ & & & $\begin{array}{c}\text { KEITH } \\
\text { WTTWER }\end{array}$ & $\begin{array}{c}\text { KEITH } \\
\text { WITWER }\end{array}$ \\
\hline \multicolumn{2}{|c|}{ DOCUMENT NO } & P.0.3615 & HNF-4359 & & & TBD & TBD \\
\hline \multirow{2}{*}{\multicolumn{2}{|c|}{$\begin{array}{l}\text { DUE DATE } \\
\text { PROIMGR }\end{array}$}} & $4 / 15 / 99$ & $6 / 15 / 99$ & & & $6 / 18 / 99$ & $7 / 28 / 99$ \\
\hline & & & & & & & \\
\hline \multirow{6}{*}{ 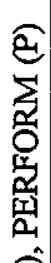 } & DES MGR & & $\mathrm{A}$ & & & $\overline{\mathrm{A}}$ & A \\
\hline & DES AGENT & $\mathrm{A}, \mathrm{W}$ & $\mathrm{A}$ & & & $\mathrm{A}$ & $\mathrm{A}$ \\
\hline & DES AUTH & $A$ & $\bar{A}$ & & & $\mathrm{~A}$ & A \\
\hline & COG MGR & & $\mathrm{A}$ & & & $\mathrm{A}$ & $\mathrm{A}$ \\
\hline & COG ENGR & A & A & & & $\mathrm{A}$ & $\mathrm{A}$ \\
\hline & QA & $\mathrm{A}, \mathrm{W}$ & $\bar{A}$ & & & $\mathrm{~A}, \mathrm{~W}$ & $\mathrm{~A}$ \\
\hline \multirow{4}{*}{ 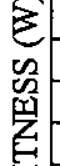 } & SAFETY & & & & & & \\
\hline & NS \& L & & & & & & \\
\hline & ENVIR & & & & & & \\
\hline & OPS & & & & & $\mathrm{A}, \mathrm{P}$ & $\mathrm{A}$ \\
\hline \multirow{2}{*}{. } & VENDOR & $\mathbf{P}$ & & & & & \\
\hline & JTRG & & & & & $\mathrm{A}$ & \\
\hline \multirow{5}{*}{. } & & & & & & & \\
\hline & & & & & & & \\
\hline & & & & & & & \\
\hline & & & & & & & \\
\hline & & & & & & & \\
\hline
\end{tabular}




\begin{tabular}{|c|c|c|c|c|c|c|c|}
\hline$\overline{\mathrm{EQ}}$ & JIP & $\begin{array}{c}\text { PREFABRI } \\
\text { CATED } \\
\text { PUMP PIT } \\
\text { MANIFOLD } \\
-2\end{array}$ & $\begin{array}{c}\text { PREFABRI } \\
\text { CATED } \\
\text { PUMP PIT } \\
\text { MANIFOLD } \\
-2\end{array}$ & $\begin{array}{c}\text { PREFABRI } \\
\text { CATED } \\
\text { PUMP PIT } \\
\text { MANIFOLD } \\
-2\end{array}$ & $\begin{array}{c}\text { PREFABRI } \\
\text { CATED } \\
\text { PUMP PIT } \\
\text { MANIFOLD } \\
-2\end{array}$ & N/A & N/A \\
\hline & $\mathrm{HOR}$ & APOLLO & $\begin{array}{c}\text { JOE } \\
\text { BUCHANAN }\end{array}$ & $\begin{array}{c}\text { KEITH } \\
\text { WITWER }\end{array}$ & $\begin{array}{c}\text { KEITH } \\
\text { WITWER }\end{array}$ & & \\
\hline & CUMENT NO & P.0.3615 & HNF-4359 & TBD & TBD & & \\
\hline & EATE & $4 / 15 / 99$ & $6 / 15 / 99$ & $6 / 4 / 99$ & $7 / 28 / 99$ & & \\
\hline & PROJ MGR & & & & & & \\
\hline al & DES MGR & & A & $\mathrm{A}$ & $\bar{A}$ & & \\
\hline 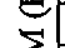 & DES AGENT & $\mathrm{A}, \mathrm{W}$ & $\mathrm{A}$ & $\mathrm{A}$ & $\bar{A}$ & & \\
\hline 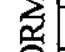 & DES AUTH & A & A & $\mathrm{A}$ & $\mathrm{A}$ & & \\
\hline 它 & COG MGR & & $\bar{A}$ & A & $\mathrm{A}$ & & \\
\hline 诖 & COG ENGR & $\mathrm{A}$ & $\mathrm{A}$ & $\mathrm{A}$ & $\mathrm{A}$ & & \\
\hline 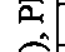 & QA & $\mathrm{A}, \mathrm{W}$ & $\mathrm{A}$ & $\mathrm{A}, \mathrm{W}$ & $\mathrm{A}$ & & \\
\hline$\varepsilon$ & SAFETY & & & & & & \\
\hline 它 & NS \& L & & & & & & \\
\hline$\tilde{\underline{I}}$ & ENVIR & & & & & & \\
\hline z & OPS & & & $\mathrm{A}, \mathrm{P}$ & $\mathrm{A}$ & & \\
\hline 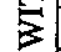 & VENDOR & P & & & & & \\
\hline की & JTRG & & & & & & \\
\hline$\Omega$ & & & & & & & \\
\hline & & & & & & & \\
\hline 电 & & & & & & & \\
\hline 言 & & & & & & & \\
\hline & & & & & & & \\
\hline
\end{tabular}




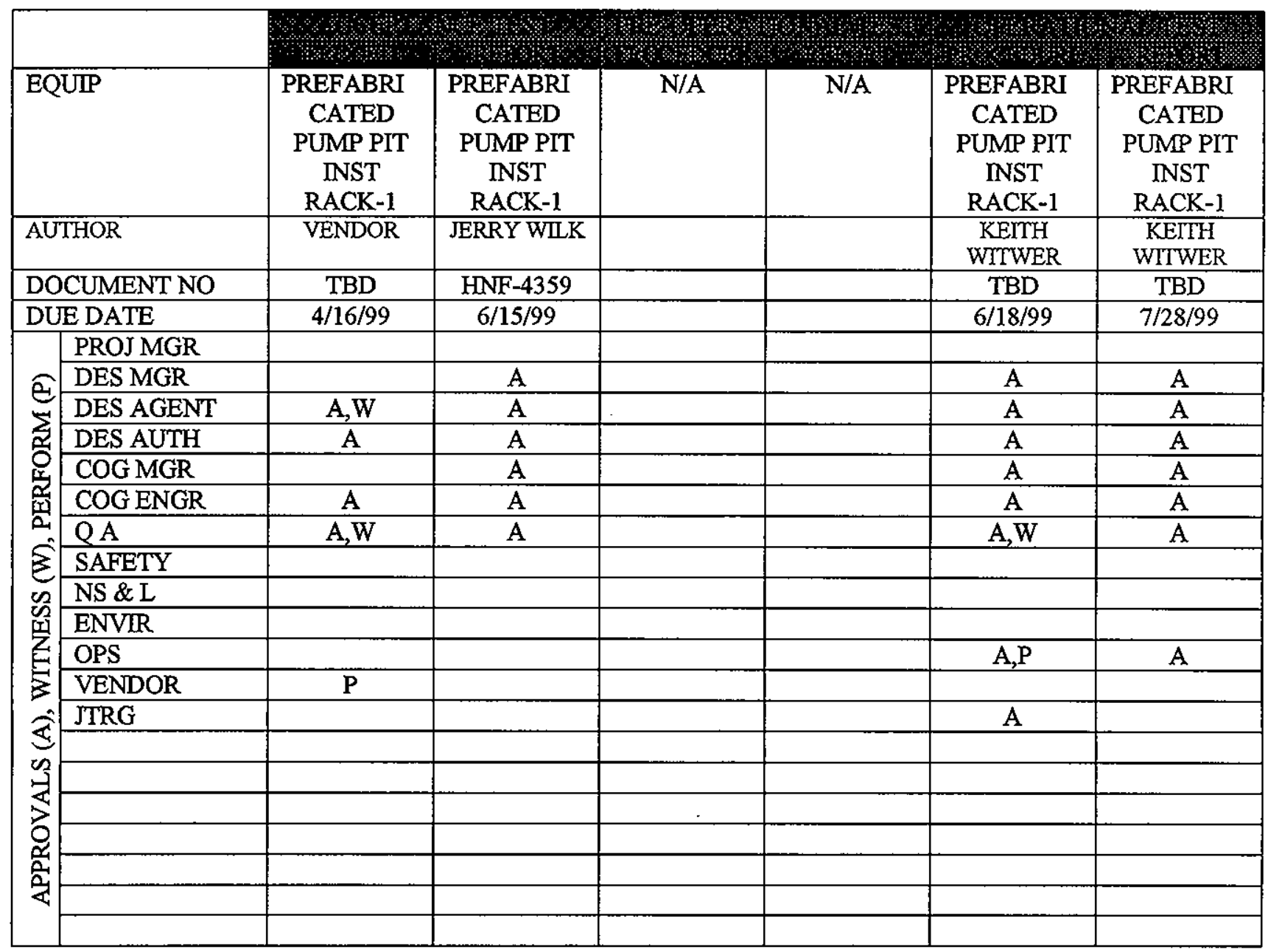




\begin{tabular}{|c|c|c|c|c|c|c|c|}
\hline \multicolumn{2}{|c|}{ EQUIP } & $\begin{array}{c}\text { PREFABRI } \\
\text { CATED } \\
\text { PUMP PIT } \\
\text { INST } \\
\text { RACK-2 }\end{array}$ & $\begin{array}{c}\text { PREFABRI } \\
\text { CATED } \\
\text { PUMP PIT } \\
\text { INST } \\
\text { RACK-2 }\end{array}$ & $\begin{array}{c}\text { PREFABRI } \\
\text { CATED } \\
\text { PUMP PIT } \\
\text { INST } \\
\text { RACK-2 }\end{array}$ & $\begin{array}{c}\text { PREFABRI } \\
\text { CATED } \\
\text { PUMP PIT } \\
\text { INST } \\
\text { RACK-2 }\end{array}$ & N/A & N/A \\
\hline \multicolumn{2}{|c|}{ AUTHOR } & VENDOR & JERRY WILK & $\begin{array}{c}\text { KETTH } \\
\text { WITWER }\end{array}$ & $\begin{array}{c}\text { KEITH } \\
\text { WITWER }\end{array}$ & & \\
\hline \multicolumn{2}{|c|}{ DOCUMENT NO } & TBD & HNF-4359 & TBD & TBD & & \\
\hline \multicolumn{2}{|c|}{ DUE DATE } & $4 / 16 / 99$ & $6 / 15 / 99$ & $6 / 4 / 99$ & $7 / 28 / 99$ & & \\
\hline \multirow{7}{*}{ 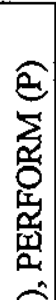 } & PROJ MGR & & & & & & \\
\hline & DES MGR & & $\mathrm{A}$ & $\mathrm{A}$ & $\mathrm{A}$ & & \\
\hline & DES AGENT & $\mathrm{A}, \mathrm{W}$ & $\mathrm{A}$ & $\mathrm{A}$ & A & & \\
\hline & DES AUTH & $\mathrm{A}$ & A & $\bar{A}$ & $\bar{A}$ & & \\
\hline & COG MGR & & $\mathrm{A}$ & $\bar{A}$ & $\mathrm{~A}$ & & \\
\hline & COG ENGR & A & $\overline{\mathrm{A}}$ & $\mathrm{A}$ & $\bar{A}$ & & \\
\hline & QA & $\mathrm{A}, \mathrm{W}$ & $\mathrm{A}$ & $\mathrm{A}, \mathrm{W}$ & A & & \\
\hline \multirow{5}{*}{ 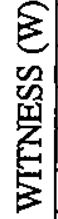 } & SAFETY & & & & & & \\
\hline & NS \& L & & & & & & \\
\hline & ENVIR & & & & & & \\
\hline & OPS & & & $\mathrm{A}, \mathrm{P}$ & $\mathrm{A}$ & & \\
\hline & VENDOR & $P$ & & & & & \\
\hline \multirow{7}{*}{ 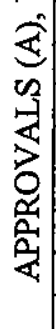 } & JTRG & & & & & & \\
\hline & & & & & & & \\
\hline & & & & & & & \\
\hline & & & & & & & \\
\hline & & & & & & & \\
\hline & & & & & & & \\
\hline & & & & & & & \\
\hline
\end{tabular}




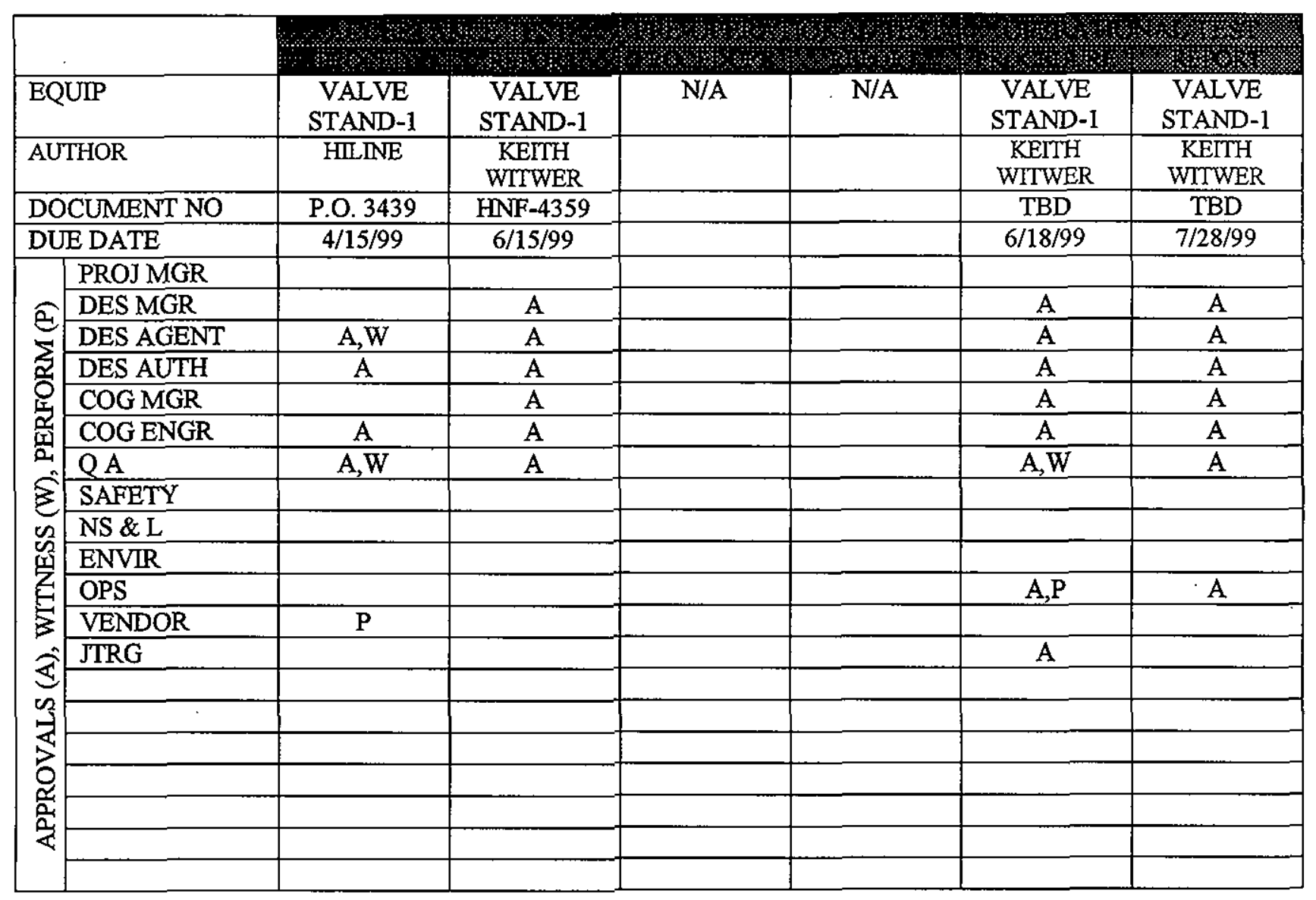




\begin{tabular}{|c|c|c|c|c|c|c|c|}
\hline \multicolumn{2}{|c|}{ EQUIP } & $\begin{array}{c}\text { VALVE } \\
\text { STAND-2 }\end{array}$ & $\begin{array}{c}\text { VALVE } \\
\text { STAND-2 }\end{array}$ & $\begin{array}{c}\text { VALVE } \\
\text { STAND-2 }\end{array}$ & $\begin{array}{l}\text { VALVE } \\
\text { STAND-2 }\end{array}$ & N/A & $\mathrm{N} / \mathrm{A}$ \\
\hline \multicolumn{2}{|c|}{$\overline{\text { AUTHOR }}$} & HIIINE & $\begin{array}{c}\text { KEITH } \\
\text { WITWER }\end{array}$ & $\begin{array}{c}\text { KEITH } \\
\text { WITWER }\end{array}$ & $\begin{array}{c}\text { KEITH } \\
\text { WTWWER }\end{array}$ & & \\
\hline \multicolumn{2}{|c|}{ DOCUMENT NO } & P.O. 3439 & HNF-4359 & TBD & TBD & & \\
\hline \multicolumn{2}{|c|}{ DUE DATE } & $4 / 16 / 99$ & $6 / 15 / 99$ & $6 / 4 / 99$ & $7 / 28 / 99$ & & \\
\hline \multirow{7}{*}{ 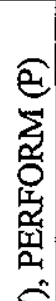 } & PROJ MGR & & & & & & \\
\hline & DES MGR & & A & $\mathrm{A}$ & A & & \\
\hline & DES AGENT & $\mathrm{A}, \mathrm{W}$ & $\mathrm{A}$ & $\mathrm{A}$ & $\mathrm{A}$ & & \\
\hline & DES AUTH & $\mathrm{A}$ & $\overline{\mathrm{A}}$ & A & $\mathrm{A}$ & & \\
\hline & COG MGR & & $\mathrm{A}$ & $\mathrm{A}$ & $\mathrm{A}$ & & \\
\hline & COG ENGR & A & $\mathrm{A}$ & A & $\mathrm{A}$ & & \\
\hline & QA & $\mathrm{A}, \mathrm{W}$ & $\bar{A}$ & $\overline{A, W}$ & $\bar{A}$ & & \\
\hline \multirow{6}{*}{ 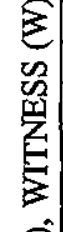 } & SAFETY & & & & & & \\
\hline & NS \& L & & & & & & \\
\hline & ENVIR & & & & & & \\
\hline & OPS & & & $\mathrm{A}, \mathrm{P}$ & $\mathrm{A}$ & & \\
\hline & VENDOR & $\mathbf{P}$ & & & & & \\
\hline & JTRG & & & & & & \\
\hline \multirow{7}{*}{ 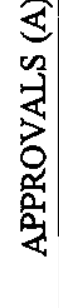 } & & & & & & & \\
\hline & & & & & & & \\
\hline & & & & & & & \\
\hline & & & & & & & \\
\hline & & & & & & & \\
\hline & & & & & & & \\
\hline & & & & & & & \\
\hline
\end{tabular}




\begin{tabular}{|c|c|c|c|c|c|c|c|}
\hline \multicolumn{2}{|c|}{ EQUIP } & $\begin{array}{l}\text { WATER } \\
\text { SKID-1 }\end{array}$ & $\begin{array}{l}\text { WATER } \\
\text { SKDD-1 }\end{array}$ & N/A & N/A & $\begin{array}{l}\text { WATER } \\
\text { SKMD-1 }\end{array}$ & $\begin{array}{l}\text { WATER } \\
\text { SKID-I }\end{array}$ \\
\hline \multicolumn{2}{|c|}{ AUTHOR } & HIIINE & $\begin{array}{c}\text { KEITH } \\
\text { WITWER }\end{array}$ & & & $\begin{array}{c}\text { KEITH } \\
\text { WTTWER }\end{array}$ & $\begin{array}{c}\text { KEITH } \\
\text { WITWER }\end{array}$ \\
\hline \multicolumn{2}{|c|}{ DOCUMENT NO } & P.O. 3439 & HNF-4359 & & & TBD & TBD \\
\hline \multicolumn{2}{|c|}{ DUE DATE } & $4 / 15 / 99$ & $6 / 15 / 99$ & & & $6 / 18 / 99$ & $7 / 28 / 99$ \\
\hline \multirow{7}{*}{ 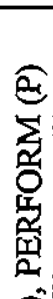 } & PROJ MGR & & & & & & \\
\hline & DES MGR & & $\bar{A}$ & & & $\mathrm{~A}$ & $\mathrm{~A}$ \\
\hline & DES AGENT & $\overline{A, W}$ & $\mathrm{~A}$ & & & $\mathrm{~A}$ & A \\
\hline & DES AUTH & $\mathrm{A}$ & $\mathrm{A}$ & & & $\mathrm{A}$ & $\mathrm{A}$ \\
\hline & COG MGR & & $A$ & & & $\mathrm{~A}$ & $\mathrm{~A}$ \\
\hline & COG ENGR & $\mathrm{A}$ & $\mathrm{A}$ & & & $\mathrm{A}$ & $\mathrm{A}$ \\
\hline & QA & $\mathrm{A}, \mathrm{W}$ & $A$ & & & $\mathrm{~A}, \mathrm{~W}$ & $\mathrm{~A}$ \\
\hline \multirow{5}{*}{ 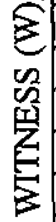 } & SAFETY & & & & & & \\
\hline & NS \& L & & & & & & \\
\hline & ENVIR & & & & & & \\
\hline & OPS & & & & & A,P & A \\
\hline & VENDOR & $\mathrm{P}$ & & & & & \\
\hline \multirow{8}{*}{ 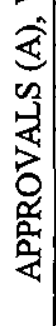 } & JTRG & & & & & $\bar{A}$ & \\
\hline & & & & & & & \\
\hline & & & & & & & \\
\hline & & & & & & & \\
\hline & & & & & & & \\
\hline & & & & & & & \\
\hline & & & & & & & \\
\hline & & & & & & & \\
\hline
\end{tabular}




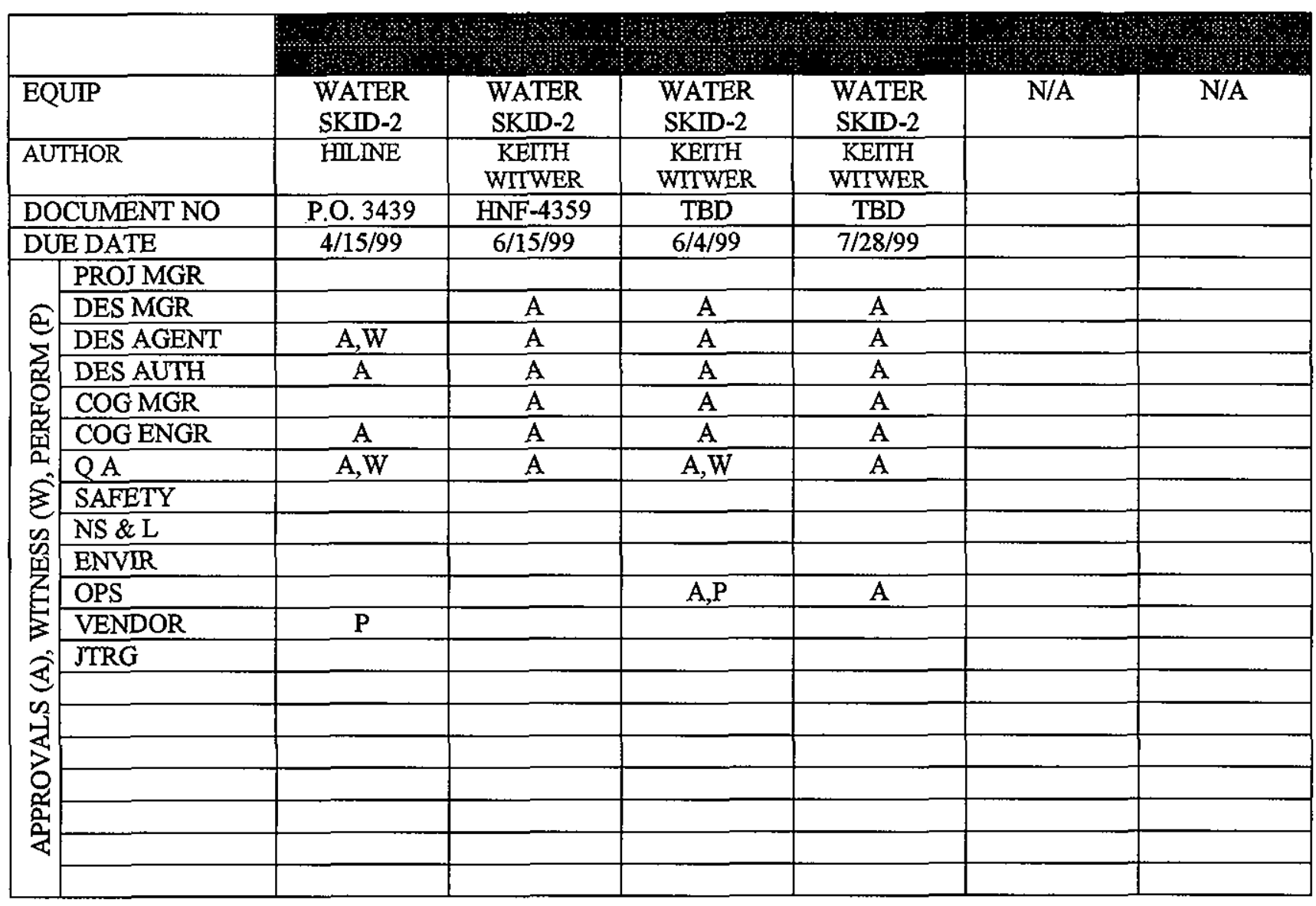




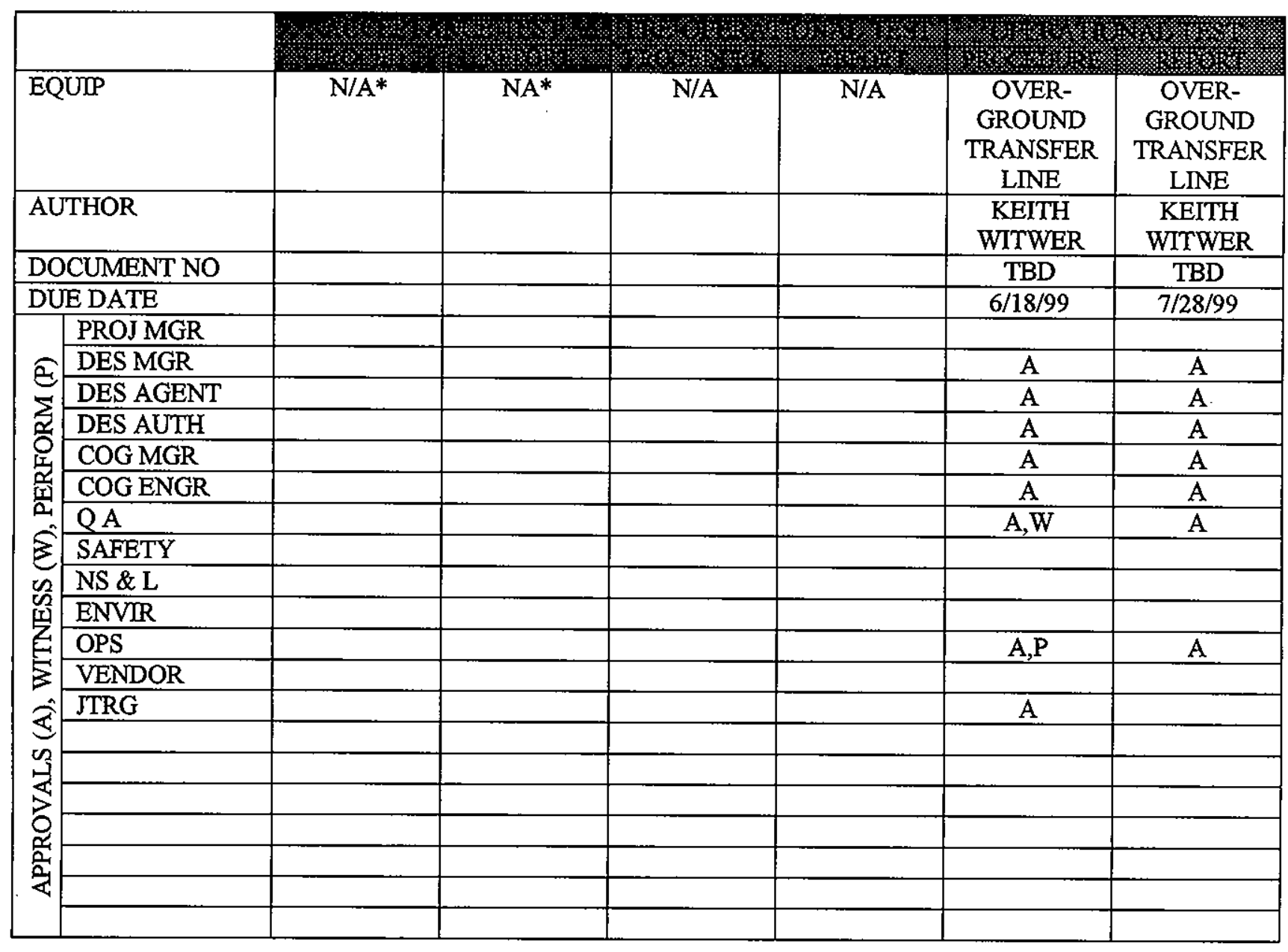

* EQUIPMENT QUALIFICATION WILL BE BY QC INSPECTION 


\begin{tabular}{|c|c|c|c|c|c|c|c|}
\hline & DROP LEG & DROP LEG & N/A & N/A & DROP LEG & DROP LEG \\
\hline \multicolumn{2}{|c|}{ AUTHOR } & VENDOR & $\begin{array}{l}\text { STEVE } \\
\text { SHAW }\end{array}$ & & & $\begin{array}{c}\text { KEITH } \\
\text { WITWER }\end{array}$ & $\begin{array}{c}\text { KEITH } \\
\text { WITWER }\end{array}$ \\
\hline \multicolumn{2}{|c|}{ DOCUMENT NO } & TBD & HNF-4359 & & & TBD & TBD \\
\hline \multirow{2}{*}{\multicolumn{2}{|c|}{\begin{tabular}{l|l}
\multicolumn{2}{l}{ DUE DATE } \\
PROJ MGR
\end{tabular}}} & $5 / 1 / 99$ & $6 / 15 / 99$ & & & $6 / 18 / 99$ & $7 / 28 / 99$ \\
\hline & & & & & & & \\
\hline \multirow{11}{*}{ D } & DES MGR & & $\mathrm{A}$ & & & $\mathrm{A}$ & A \\
\hline & DES AGENT & $\mathrm{A}, \mathrm{W}$ & $\mathrm{A}$ & & & A & A \\
\hline & DES AUTH & $\mathrm{A}$ & $\mathrm{A}$ & & & A & A \\
\hline & COGMGR & & $\bar{A}$ & & & $\mathrm{~A}$ & $\bar{A}$ \\
\hline & COG ENGR & A & A & & & $\mathrm{A}$ & $\mathrm{A}$ \\
\hline & QA & $\mathrm{A}, \overline{\mathrm{W}}$ & $\mathrm{A}$ & & & $\mathrm{A}, \mathrm{W}$ & $\mathrm{A}$ \\
\hline & SAFETY & & & & & & \\
\hline & NS\&L & & & & & & \\
\hline & ENVIR & & & & & & \\
\hline & OPS & & & & & $\bar{A}, \bar{P}$ & A \\
\hline & VENDOR & $\mathrm{P}$ & & & & & \\
\hline \multirow{7}{*}{ 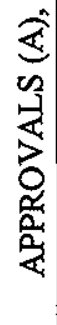 } & JTRG & & & & & $\mathrm{A}$ & \\
\hline & & & & & & & \\
\hline & & & & & & & \\
\hline & & & & & & & \\
\hline & & & & & & & \\
\hline & & & & & & & \\
\hline & & & & & & & \\
\hline
\end{tabular}




\section{DISTRIBUTION SHEET}

\begin{tabular}{|l|l|}
\hline To & From \\
SY-101 PROJECT & R.E. BAUER \\
\hline
\end{tabular}

Project Title/Work Order

TANK 241-SY-IOI SURFACE LEVEL RISE REMEDIATION TEST AND EVALUATION PLAN FOR TRANSFER SYSTEM

Name

G.A. LESHIKAR

T.R. BENEGAS

K.L. MORRIS

C.E. HANSON

R.W. REED

M.F. ERHART

L.S. KROGSRUD

M.L. MCELROY

R.E. RAYMOND

W.J. POWELI

J.R. BIGGS

S.W. SHAW

$J . R$ BUCHANAN

J.P. KING

K.W. WITWER

W.B. BARTON

S.D. ESTEY

F.M . HAUCK

R.M. PIERSON

G.A. BARNES

M.H. BROWN

R.L. SCHLOSSER

K.N. JORDAN

R.E. BAUER

A.F. ERHART

J.L. WILK

N.W. KIRCH

J.M. GRIGSBY

R.E. MERRIMAN

R.J. BROWN

R.L. LEGG

D.O. DOBSON

\begin{tabular}{|c|c|c|c|c|}
\hline MSIN & $\begin{array}{c}\text { Text } \\
\text { With All } \\
\text { Attach. }\end{array}$ & Text Only & $\begin{array}{c}\text { Attach./ } \\
\text { Appendix } \\
\text { Only }\end{array}$ & $\begin{array}{c}\text { EDT/ECN } \\
\text { Only }\end{array}$ \\
\hline$G I-54$ & $\mathrm{x}$ & & & \\
\hline G1-54 & $x$ & & & \\
\hline $\mathrm{G} 1-54$ & $\mathrm{X}$ & & & \\
\hline $\mathrm{G} 1-54$ & $\mathrm{x}$ & & & \\
\hline T4-07 & $\mathrm{x}$ & & & \\
\hline GI-54 & $\mathrm{x}$ & & & \\
\hline T4-07 & $\mathrm{x}$ & & & \\
\hline GI-54 & $\mathrm{x}$ & & & \\
\hline $\mathrm{G} 1-54$ & $\mathrm{x}$ & & & \\
\hline GI-54 & $\mathrm{x}$ & & & \\
\hline$G I-54$ & $\mathrm{x}$ & & & \\
\hline G1-54 & $\mathrm{x}$ & & & \\
\hline G1-54 & $\mathrm{x}$ & & & \\
\hline $\mathrm{G} 1-54$ & $x$ & & & \\
\hline G1-54 & $\mathrm{x}$ & & & \\
\hline R2 - 12 & $\mathrm{X}$ & & & \\
\hline $\mathrm{R} 2-12$ & $\mathrm{x}$ & & & \\
\hline A3-04 & $\mathrm{x}$ & & & \\
\hline$s 6-14$ & $\mathrm{x}$ & & & \\
\hline G1-54 & $\mathrm{X}$ & & & \\
\hline T4-07 & $\mathrm{X}$ & & & \\
\hline$R I-56$ & $\mathrm{x}$ & & & \\
\hline $\mathrm{G} 1-54$ & $x$ & & & \\
\hline G1-54 & $\mathrm{x}$ & & & \\
\hline $\mathrm{G} 1-54$ & $\mathrm{x}$ & & & \\
\hline G1-54 & $\mathrm{x}$ & & & \\
\hline R2-I1 & $x$ & & & \\
\hline R1-49 & $x$ & & & \\
\hline R1-49 & $\mathrm{x}$ & & & \\
\hline G1-54 & $x$ & & & \\
\hline$R 4-06$ & $x$ & & & \\
\hline R4-06 & $x$ & & & \\
\hline
\end{tabular}




\section{DISTRIBUTION SHEET}

To

SY-101 PROJECT

Project Title/Work Order

TANK 241-SY-101 SURACE LEVEL RISE REMEDIATION TEST AND EVALUATION PLAAN FOR TRANSFER SYSTEM

\begin{tabular}{l}
\hline CENTRAL FILES \\
\hline DOE/RL READING ROOM
\end{tabular}

From

R. E. BAUER

Name

\begin{tabular}{c|c|c|c|c} 
MSIN & $\begin{array}{c}\text { Text } \\
\text { With All } \\
\text { Attach. }\end{array}$ & Text Only & $\begin{array}{c}\text { Attach./ } \\
\text { Appendix } \\
\text { Only }\end{array}$ & $\begin{array}{c}\text { EDT/ECN } \\
\text { Only }\end{array}$ \\
\hline B1-07 & $\mathrm{X}$ & & & \\
\hline H2-53 & $\mathrm{X}$ & & & \\
\hline
\end{tabular}

Page 2 of 2

Date MAY 13, 1999

EDT No. 626340

ECN No.

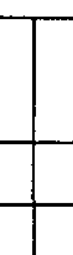

$2-53$ 